\title{
SOME NEW COBBETTIANA
}

\author{
BY JOHN W. OSBORNE
}

7 HE outstanding Cobbett collection of the Rutgers University Library has recently been fortified by some letters 1 written by Cobbett as well as a few miscellaneous writings
relating to the Rural Rider. ${ }^{1}$ The latter mainly concern efforts to secure funds for a monument to Cobbett after his death in June, I 835 .

The letters written by Cobbett are more interesting. Most of them were sent to John Fielden, member of parliament from Oldham and Cobbett's partner in representing that Lancashire industrial town in the House of Commons. None of the letters were dated earlier than June, 1832 and they reveal something of Cobbett's activities during the last few years of his life.

Cobbett was always brisk in a letter. He was never fond of circumlocution or verbosity and, like his articles in the Political Register, he made his point effectively in correspondence. One letter from Dublin written in September, 1834 describes the misery in Ireland which Cobbett saw at first hand during a visit. Another, written in July of the same year, asked Fielden for a loan of $\mathfrak{t}_{\text {I }} 50$ for "housekeeping expenses"-the nearest this collection of Cobbett's correspondence gets to his unhappy family situation during the last few years of his life. Cobbett scholars eagerly await each new discovery of papers relevant to Cobbett's life and career for information on this subject for, alas, it is clear that some previous correspondence which shed light on the situation has been destroyed.

Perhaps the most interesting letters to Fielden are those which refer to Cobbett's health. For several years prior to his death, Cobbett suffered from hoarseness and inflammation in his throat which was either caused or aggravated by the unhealthy House of Commons chamber where he sat. Now we find him writing in April, I 834 that "My cough goes on in its old way" and in the following month he told Fielden that he expected to return to the House of Commons on May 25 if his health permitted. ${ }^{2}$ But ill or not, Cobbett

\footnotetext{
${ }^{1}$ For a succinct statement of Cobbett's life and significance, see John W. Osborne's article, "William Cobbett" in the latest (1 $5^{\text {th }}$ edition) of the Encyclopedia Britannica.

${ }^{2}$ On May 26, 1834 Cobbett did speak in parliament on the subject of the poor law, Hansard, 3rd Series. Vol. 23, cols. 1319-1 320.
} 
was always the optimist and in the same letter that began with a complaint about his cough, he claimed that "The Revolution has begun. ... . That 'Great Change,' which you anticipated is certainly at hand!" Still, the frequent references to bad health in those letters allows us to appreciate Cobbett's courage in making his Irish tour late in 1834 (despite its depressing revelations, the tour acted as a tonic to Cobbett's health). The letters also help to reduce the suspicion that Cobbett's frequent absences from parliament in that year were due to the blows to his vanity which his lack of ability to influence affairs in parliament inflicted.

Not all of Cobbett's letters were addressed to Fielden. One was sent to Lord Duncannon (John William Ponsonby), Home Secretary in Lord Melbourne's Whig government pleading for some Oldham men who were sentenced to transportation. But perhaps the most characteristic of all was a note to Fielden from Cobbett's London headquarters at Bolt-Court. The letter has no date and was obviously written in haste and irritation. It says, "The damned Italian villains were noising in this court, when I was going to bed last night; instead of the voice of the Nightingales and blackbirds and wood-pidgeons, which has accompanied my couchee for a month past! I wish every musician in the world was strangled."

Finally, there is a letter from William Cobbett Junior to Fielden dated October 28, I 835-over four months after Cobbett's deathasking the humanitarian Lancashire manufacturer for a $£ 50$ loan to pay off a debt and to enable the Political Register to carry on. Controversial in life, Cobbett was also a source of friction after he died, for his son's bitter letter claims that Cobbett's friends who were trying to raise a monument to him had somehow held back money from the estate. This is all very curious, for William Cobbett Junior was a barrister and of course was not only Cobbett's executor but was himself well versed in the law. In any event, the Political Register did not long outlive the man who had been its heart and soul for over thirty years. 